\author{
Melanie Lewis \\ University of West Georgia \\ mlewis@westga.edu
}

\title{
Enabling School Librarians to Serve as Instructional Leaders of Multiple Literacies Introduction and Problem
}

\begin{abstract}
Research has demonstrated that school leaders have little to no understanding of the instructional leadership role of the school librarian and have received little to no training in how to lead this population (Lewis, 2018; 2019). Though the standards of the school library field state that school librarians should be equipped and able to serve as instructional leaders of multiple literacies in K-12 education, barriers exist that inhibit this from becoming a reality in many schools. One of these barriers is a lack of administrative support in the form of a district library supervisor to develop a vision for and provide support to the district's school library program and its personnel. Very little research has been conducted to examine the support needs of in-service school librarians (Weeks et al., 2017), and no research has been conducted to explore how to equip existing leadership to effectively lead its population of school librarians in a school district that lacks an official district library supervisor. The purpose of this study is to explore how school district leaders can foster the development of an effective school library in which school librarians serve as instructional leaders of multiple literacies.
\end{abstract}

Keywords: school librarians, leadership, instructional leaders

\section{Literature Review}

Specific barriers to school librarian leadership have been identified by researchers. These include a lack of clarity in role definition, insufficient district-level support, insufficient staffing, a district-wide emphasis on testing, and resistant teachers (Lewis, 2018, 2019; Calvert, 2016; Elkins, 2018; Johnston, 2012; Hughes-Hassell \& Hanson-Baldauf, 2008; Merga, 2020). Conversely, research has revealed specific supports that enable school librarians to serve in leadership roles. These supports are primarily realized through positive relationships, particularly between a supportive principal and a school librarian (Lewis, 2018, 2019; Johnston, 2012; Lupton, 2016; Merga, 2020). Other important relationships consist of collegial and collaborative partnerships with a district library supervisor (DiScala et al., 2019; Johnston 2012; Weeks et al., 2017) and classroom teachers (Ash-argyle, 2012; Harada, 2016; Lance \& Kachel, 2018; Merga 2020; Montiel-Overall, 2010). 


\section{Method}

An exploratory case study was employed for this qualitative research. The bounded system for this study was a comprehensive PK-12 public school district that employed building-level school librarians but did not employ a full-time district library supervisor. Participants included district-level personnel and building-level school librarians. The district-level personnel consisted of those that held leadership roles in areas related to the school library program: curriculum and instruction, professional development, and instructional technology. Data were collected from multiple sources, including interviews, focus groups, documents, and observations. An exploratory method of coding was employed to organize the data into categories from which three themes emerged: a) ambiguous expectations, b) inability to fully engage with the instructional program, and c) relationships. The themes were then interpreted to develop a naturalistic generalization of the case.

\section{Findings}

Results revealed that ambiguous expectations prevent school librarians from fully engaging with the K-12 instructional program and that clear expectations and positive relationships serve as powerful supports for enabling school librarians to serve as instructional leaders of multiple literacies. A lack of clarity in role definition and insufficient district-level support are the primary barriers that contribute to ambiguous expectations. Insufficient staffing, a school-wide emphasis on testing, and resistant teachers are the barriers that contribute to a school librarian's inability to fully engage with the instructional program. Positive relationships between school librarians and a district library supervisor, a supportive principal, classroom teachers, and other school librarians were identified as the primary supports needed to engage in instructional leadership.

\section{Discussion}

The influx of technologies into K-12 instructional programs in the form of hardware devices and digital programs has compounded the lack of clarity in role definition for school librarians. As the responsibilities for providing technical support for these technologies has fallen upon school librarians, their ability to serve as instructional leaders has decreased. School personnel have come to view the school librarian as a technical support provider and manager of digital accounts rather than a fellow educator who can assist them with integrating these technologies into the existing curriculum to positively impact student achievement. The school librarians in this study currently have little to no opportunity to address the district's technology initiative focused upon achieving student learning outcomes that address the higher-level cognitive aspects of literacy. They are instead relegated to dealing with the lower-level technical aspects of literacy, namely, how to access and functionally use resources outside the context of the curriculum.

\section{Implications}


The results of this study have identified specific supports needed for both district leaders and school librarians to develop an effective school library in which school librarians serve as instructional leaders of multiple literacies. First, a clear vision for how school librarians should be utilized at each school site within the school district must be established. Given available resources, a decision must be made to determine how the school librarian can best impact student achievement. School librarians without sufficient clerical, operational, and technical support staff will likely only be able to facilitate the daily circulation and technical duties required within the physical library space. They will be restricted to serving solely as a manager of physical and digital resources. To serve as an instructional leader, the school librarian will need full-time support staff to be able to focus upon collaborating with classroom teachers, engaging with the instructional program, and interacting with students within a classroom environment.

Once the vision for school librarians has been established, clear expectations must be set to align with this vision. At the district level, an administrator who possesses the appropriate certification and experience in school librarianship is needed to provide direction and support to district leaders, school site leaders, and school librarians. Finally, school librarians need their school districts to provide ongoing professional learning that is tailored to their distinct role.

\section{References}

Ash-argyle, R. (2012). Librarians' leadership efficacy, training, and school involvement: collaboration between teachers and school librarians in Israel. School Libraries Worldwide, 18(1), 1-17.

Calvert, P. (2016). School libraries in New Zealand as technology hubs: Enablers and barriers to school librarians becoming technology leaders. School Libraries Worldwide, 22(2), $51-62$.

DiScala, J., Weeks, A. C., \& Kodama, C. (2019). The school district library supervisor and the national school library standards. Knowledge Quest, 47(5), 64-72.

Elkins, A. J. (2018). Mind the gaps: School librarians' job descriptions and the professional standards for school librarians in the United States. School Libraries Worldwide, 24(1), $87-98$.

Harada, V. (2016). A practice-centered approach to professional development: Teacher-librarian collaboration in capstone projects. School Library Research, 19, 1-47.

Hughes-Hassell, S., \& Hanson-Baldauf, D. (2008). Information and communication technology use by North Carolina school library media specialists: Perceived competencies and barriers. School Library Media Research, 11, 1-24.

Johnston, M. P. (2012). School librarians as technology integration leaders: Enablers and barriers to leadership enactment. School Library Research, 15, 1-33.

Lance, K. C., \& Kachel, D. E. (2018). Why school librarians matter: What years of research tell us. Phi Delta Kappan, 99(7), 15-20. 
Lewis, M. A. (2019). Administrators' instructional leadership perspective of the role of instructional coaches and teacher librarians: A comparative examination. School Libraries Worldwide, 25(2), 16-33. DOI:10.14265.25.2.002

Lewis, M. A. ( 2018). A collective case study to examine administrators' instructional leadership perspective of the role of instructional coaches and teacher librarians in California public schools. [Doctoral dissertation, Liberty University.] $<$ https://digitalcommons.liberty. edu/doctoral/1663> (accessed Dec. 16, 2019).

Lupton, M. (2016). Adding value: Principals' perceptions of the role of the teacher-librarian. School Libraries Worldwide, 22(1), 49-61.

Merga, M. K. (2020). School librarians as literacy educators within a complex role. Journal of Library Administration, 60(8), 889-908. https://doi.org/10.1080/01930826.2020.1820278

Montiel-Overall, P. (2010). Further understanding of collaboration: A case study of how it works with teachers and librarians. School Libraries Worldwide, 16(2), 31-54.

Weeks, A. C., DiScala, J., Barlow, D. L., Massey, S. A., Kodama, C., Hall, R., Jarrell, K., Jacobs, L., Moses, A., \& Follman, R. (2017). The lilead survey: A national study of district-level library supervisors: Roles, responsibilities, challenges, and professional development needs. School Library Research, 20, 1-28. 